\title{
Development Potentials of Rural Areas - The Case of Slovenia
}

\author{
Anton Perpar and Andrej Udovč \\ University of Ljubljana, Biotechnical Faculty \\ Slovenia
}

\section{Introduction}

Rural areas in the European Union (27 member states) make up 91\% of the territory and over $56 \%$ of the population (European Commission, 2008). They include a great variety of cultures, landscapes, natural environments, and economic activities that shape different rural identities. Farming and forestry remain crucial for land use and the management of natural resources in the EU's rural areas, and as a platform for economic diversification in rural communities. In Slovenia as well, rural areas represent a significant part of its space and society. Slovenia is one of the smallest European countries, sharing borders with Italy, Austria and Croatia. 2,050,189 people live in a land area of 20,273 $\mathrm{km}^{2}$, for an average population density of 101,1 inhabitants per $\mathrm{km}^{2}$ (January 1st 2011). In 2010, the country's gross domestic product (GDP) per capita was 17,560€. Slovenia's location between the Alps, the Dinaric mountains, the Adriatic Sea and the Pannonian Plain is the reason for the country's diverse climate: there is a continental climate in central Slovenia, an Alpine climate in the northwest, and a sub-Mediterranean climate in the coastal area and its hinterlands. Consequently, landscapes and agricultural production conditions are also diverse, as are the cultural identities of individual rural areas. Based on the 2002 population census, rural areas make up more than $90 \%$ of the territory and are inhabited by $58 \%$ of the total population (Perpar, 2007). The Slovenian countryside is highly heterogenous, distinguished by various natural conditions and obstacles, and diversified demographic, economic, and social structures (Perpar \& Kovačič, 2002).

In recent decades rural areas have been exposed to many different changes and challenges, and have had to cope with a range of economic and societal needs, some of them new. Agricultural and forestry activities make rural areas the most important providers of food, and important contributors to the production of fibers and construction materials. Furthermore, rural areas are increasingly important as centers of energy production, from biomass and other renewable sources such as water resources, and have rich biodiversity and highly varied natural environments. They are also important from an economic aspect since new economic sectors are now developing in rural areas, such as rural tourism and other activities linked to their natural and cultural assets. But they are relatively isolated areas, removed from the centers of decision-making, economically and socially heterogeneous, largely dependent on natural resources, highly sensitive to exogenous modernization dynamics through linkages with urban areas, with often a kind of collective 
sense of lasting crisis and a deterministic and fatalistic vision of the future. At the same time, rural areas are a specific type of complex system, a social-ecological system shaped by the relationships between ecological and human subsystems (Ambrosio-Albalá \& Bastiaensen, 2010), and characterized by an intrinsic fragility in economic, environmental and social terms. Rural development is therefore a vitally important policy area world-wide.

\subsection{Defining rural development, its aims and sustainability}

The concept of rural development has changed significantly during the past few decades. Until the 1970s, rural development was synonymous with agricultural development, and focused on increasing agricultural production (Fernando, 2008). This focus has been driven primarily by the interests of industrialization to extract surpluses from the agricultural sector to reinforce industrialization (Francks et al., 1999, as cited in Fernando, 2008). In the early 1980s the concept changed and now encompasses "concerns that go well beyond improvements in growth, income, and output". These concerns include an assessment of changes in the quality of life, broadly defined to include improvement in health and nutrition, education, environmentally safe living conditions, and reduction in gender and income inequalities (Chino, 2000, as cited in Fernando, 2008). Today there seems to be a universal consensus that the ultimate objective of rural development is to improve the quality of life of rural people.

Rural development is therefore a continuous process facilitated by governments, nongovernmental organizations (NGOs) and different actors at the international, national and local levels, to sustain the growth of rural economies, improve the livelihoods of rural communities and to promote food security through the improvement of food supply, employment and income (Halwart et al., 2003).

According to De Haas et al. (1997, as cited in Elands \& Wiersum, 2001) rural development comprises two dimensions: contents and process. The contents of rural development concern the implementation of a large variety of measures aiming at improvement of the rural economy, the quality of life of the community, the landscape identity, the protection of the environment, and the attractiveness of rural areas (Elands \& Wiersum, 2001; ECRD, 1996). Regarding the process dimension of rural development, a major aspect to be considered is the renewal of rural institutions, procedures and culture, and their impact on the rural space. Institutional renewal should enable innovating processes and practices to be applied to the use of the rural space. In this context, much attention is given to community participation and involvement in rural development efforts.

Sustainable rural development can be defined as a process of multidimensional change affecting rural systems (Polidori \& Romano, 1996, as cited in Pugliese, 2001). Economic growth, improvement of social conditions, and conservation of natural values are all equally important features in sustainable rural development, which should be induced according to a bottom-up approach, through the participation and sustainable use of local endogenous resources (environment, labor force, knowledge, patterns of production, consumption, and communication). Sustainable rural communities should be able to recognize and internalize exogenous chances of growth, i.e. markets, policies, and technology opportunities, properly integrating and balancing them with the need to preserve and enhance rural specificities and diversity (Long \& Van der Ploeg, 1994, as cited in Pugliese, 2001). 


\subsection{Exogenous and endogenous rural development model}

Often two processes are distinguished: exogenous and endogenous development (Van der Ploeg \& Long, 1994; Lowe et al., 1995; Nemes, 2005) (Table 1). Exogenous development is conceived as a process in which rural development is the result of forces emanating from outside rural areas; it is externally determined (Slee, 1994). Such forces consist of both economic market forces and (inter)national government policy measures. This kind of model was common in the first decades after World War II, when many European countries invested in rural regions, and investments were used mainly for branch plants, relocation of firms, the creation of growth poles and improvements in infrastructure (Terluin, 2001). Terluin notes that the impact of this model on the rural economy was not always successful. Expected multipliers of the new firms in terms of linkages with local firms, benefits of skill formation, technology transfer and reinvestment of profits in the rural economy did not often occur. Lowe et al. (1995) notes that recession in the 1970s resulted in the closure of many branch plants and a growing sense that inward investments made rural economies highly vulnerable to fluctuations in the global market and distant boardroom decisions. In contrast, endogenous development is conceived as a process in which rural development is the result of local initiatives (Elands \& Wiersum, 2001) and grounded largely in local resources (Terluin, 2001). The benefits of development tend to be retained in the local economy and local values are respected (Slee, 1994). Terluin (2001) as prerequisites for the success of the endogenous model notes intensive interaction, information exchange and cooperation among local actors, while special attention should be given to improvement of infrastructure. These two processes are often characterized as being 'top-down' and 'bottom-up', respectively. Traditionally, the exogenous model dominated thinking concerning rural development. However, at present a major concern regarding the process of rural development is the need to strengthen endogenous development by stimulating local community initiatives and bottom-up planning processes (Van der Ploeg \& Long, 1994).

\begin{tabular}{|c|c|c|}
\hline & Exogenous development & Endogenous development \\
\hline Key principle & $\begin{array}{l}\text { Economies of scale and } \\
\text { concentration }\end{array}$ & $\begin{array}{l}\text { Use of local (natural, human } \\
\text { and cultural) resources for } \\
\text { sustainable development }\end{array}$ \\
\hline Dynamic force & $\begin{array}{l}\text { Urban growth poles (drivers } \\
\text { exogenous to rural areas) }\end{array}$ & Local initiative and enterprise \\
\hline $\begin{array}{l}\text { Functions of rural } \\
\text { areas }\end{array}$ & $\begin{array}{l}\text { Food and primary products for } \\
\text { expanding urban economies }\end{array}$ & Diverse service economies \\
\hline $\begin{array}{l}\text { Major rural } \\
\text { development problems }\end{array}$ & $\begin{array}{l}\text { Low productivity and } \\
\text { peripherality }\end{array}$ & $\begin{array}{l}\text { Limited capacity of areas and } \\
\text { groups to participate in } \\
\text { economic activity }\end{array}$ \\
\hline $\begin{array}{l}\text { Focus of rural } \\
\text { development }\end{array}$ & $\begin{array}{l}\text { Agricultural modernisation: } \\
\text { encourage labour and capital } \\
\text { mobility }\end{array}$ & $\begin{array}{l}\text { Capacity buildings (skills, } \\
\text { institutions, infrastructure): } \\
\text { overcoming exclusion }\end{array}$ \\
\hline Criticism & $\begin{array}{l}\text { Dependent, distorted, } \\
\text { destructive and dictated } \\
\text { development }\end{array}$ & $\begin{array}{l}\text { Not practical in contemporary } \\
\text { Europe }\end{array}$ \\
\hline
\end{tabular}

Source: Galdeano-Gómez et al., 2010.

Table 1. Exogenous and endogenous rural development models 
Endogenous approaches are based on the assumption that the specific resources of an area (natural, human and cultural) hold the key to its sustainable development (GaeldanoGómez et al., 2010). Whereas exogenous rural development saw its key challenge as overcoming rural differences and distinctiveness through the promotion of universal technical skills and the modernisation of physical infrastructure, endogenous development sees the key challenge as valorising difference through the nurturing of locally distinctive human and environmental capacities (Gaeldano-Gómez et al., 2010; Van der Ploeg \& Long, 1994; Van der Ploeg \& Dijk, 1995; Shucksmith, 2000). In this model local resource endowments (climate, land fertility and environmental quality) and the specific characteristics of human and cultural capital provide the fundamental conditions for longterm rural development. The main purpose of this perspective is to improve local economic and social circumstances through mobilising internal resources.

Some authors (Lowe et al., 1993; Nemes, 2005) have criticized endogenous development perception. The argumentation is that the notion of local rural areas pursuing socioeconomic development without outside influences (such as globalization, external trade, governmental actions, etc.) may be ideal but it is not a realistic proposition in contemporary Europe. Terluin (2001), too, notes that today, in the global perspective, rural areas are affected by all kind of global forces. This implies that the development process in rural areas is largely dependent on the interplay of local (endogenous) responses and global (exogenous) forces. Both of them are mediated through national structures in which local actors should seek room for maneuver so as to determine the outcome of the process. Terluin also talks about the mixed exogenous/endogenous approach, which rejects the polarization between the two models. It relates rural development to the process of increasing globalization, mainly due to rapid changes in the information and communication technologies. In a changing global context, actors in rural areas are involved in both local and external networks, but the size, direction and intensity of networks vary among regions. Galdeano-Gómez et al. (2010) notes that the critical point is how to enhance the capacity of local areas to steer these wider processes, resources and actions to their benefit. This is the notion of neo-endogenous development (Table 2). The focus then is on the dynamic interactions between local areas and their wider political, institutional, trading and natural environments, and how these interactions are mediated.

\begin{tabular}{|l|l|}
\hline & Neo-endogenous development \\
\hline Key principle & The interaction between local and global forces \\
\hline Dynamic force & $\begin{array}{l}\text { Globalisation, rapid technological change in } \\
\text { communications and information }\end{array}$ \\
\hline Functions of rural areas & $\begin{array}{l}\text { Knowledge economy, dynamic participation of local actors } \\
\text { in local and external networks and development process }\end{array}$ \\
\hline $\begin{array}{l}\text { Major rural development } \\
\text { problems }\end{array}$ & $\begin{array}{l}\text { Resources allocation and competitiveness in a global } \\
\text { environment }\end{array}$ \\
\hline Focus of rural development & $\begin{array}{l}\text { Enhancing local capacity and actors participation to direct } \\
\text { local and external forces to their benefit }\end{array}$ \\
\hline Criticism & Operates at a level of insufficient empirical evidence \\
\hline
\end{tabular}

Source: Galdeano-Gómez et al., 2010.

Table 2. Neo-endogenous rural development model 
Neo-endogenous rural development follows the arguments that rural areas are not isolated but part of a globalized world, so exogenous forces should also be taken into account. It means that the key to local development lies in building a local institutional capacity able to both mobilize internal resources and cope with the external forces acting on a region (GaldeanoGómez et al., 2010). This perspective emphasizes not only that economic or business development needs to be embedded in the region, but that the means of achieving this objective is through the participation of local actors in internal and external development processes. Central to the approach is that a local area has, or must acquire, the capacity to assume some responsibility for bringing about its own socio-economic development (Ray, 2006). Neo-endogenous development has two primary characteristics. First, economic and other development activity is reoriented to maximize the retention of benefits within the local territory by valorizing and exploiting local resources (physical and human). Second, the development is contextualized by focusing on the needs, capacities and perspectives of local people.

\subsection{The aims of rural development}

The aims and approaches to rural development between countries differ but the overall goal is to maintain socio-economic vitality of rural communities and sustainable development of rural areas. The aims of rural development can be achieved through the reduction of comparative disadvantages for competition and the finding of new ways to reinforce and utilize rural resources (Nemes, 2005). Main rural development efforts are focused on the equalization of income among rural and urban residents, equal access to social and economic services, creation of equal employment opportunities, providing freedom of choice of residence and work, and maintaining the identity of rural communities (OECD, 1998).

The objectives of rural development in OECD member countries are different, but there it is also a different relative importance of each objective. In general key objectives of rural development policies are the following (OECD, 1998):

- increasing competitiveness of rural areas and maximizing their contribution to general economic development,

- providing opportunities for the rural population to achieve a living standard comparable to national norms,

- conserving and developing the natural environment and cultural heritage of rural areas,

- maintaining the population of rural areas, and where depopulation is already going on trying to stop the process,

- improving farm income and promoting different employment opportunities to compensate for decreasing employment in agriculture,

- improving living conditions in rural areas and decreasing the differences in living and working conditions between rural and urban areas,

- preserving and developing landscape and protecting the natural and cultural environment.

Theories related to agriculture and rural development in general distinguish two approaches (Barbič, 1990): a sectoral or partial approach where development is focused on the development of one specific area (i.e. agriculture, forestry, infrastructure, services, tourism, 
etc.) and an integrated approach as a comprehensive development that reflects the complex linkages and interactions within the rural system (Kostov \& Lingard, 2001).

\section{Development potentials of rural areas}

In recent decades literature in the field of rural development has dealt mainly with development problems and possibilities. Today's new terminology and methodology of rural studies focus mostly on the identification and evaluation of various "types of capital" that rural areas have (economic, human, social, cultural and environmental) and their endogenous development potential. Several studies (for example, the DORA (Dynamics of Rural Areas) and RUREMPLO (Rural Employment) projects) have tried to answer why some rural regions show better economic performance than others. General findings are that economic performance is multi-dimensional and influenced by the complex interplay between economic, human, social, cultural and environmental capital, which is unevenly distributed among rural areas (Agarwal et al., 2009). Economic capital relates generally to "capital resources that are invested and mobilized in pursuit of profit" (Lin, 2001). Human capital may be associated with individuals and relates to the skills and knowledge that individuals possess as well as the demographic characteristics and quality of life of an area. Social capital refers to connections among individuals and social networks and to the reciprocity which arises from these connections (Putnam, 2000, as cited in Agarwal et al., 2009). Cultural capital according to Bourdieu (as cited in Agarwal et al., 2009) derives its analytical contribution from notions of social practice and from the social reproduction of symbols and meanings. Environmental capital plays a key role in encouraging or limiting economic growth and development. The growing perception of the rural environment as an area of consumption combined with the increase in "green" consumerism has created opportunities for both farmers and entrepreneurs, particularly in those environments which are endowed with high quality natural assets. Thus, the quality of the environment is proving to be of increasing importance to the economic growth, development and performance of rural areas, particularly in light of changes in agriculture and the growth of tourism and recreation (Hoggart et al., 1995).

Rural areas thus have different types of capital, and each type has different development resources or potential. Potočnik Slavič (2010) defined "development potential" as the resources, attractiveness and capital of a particular area which can be used today or in the future for its sustainable development. Factors affecting the exploitation of the resources, attractiveness and capital are their availability, utility, accessibility, technology, the market, etc. Endogenous development potential forms the basis for the development of different activities in rural areas (agriculture and forestry, entrepreneurship, tourism, recreation, residence, etc.). Resources and attractiveness are foundations upon which different kinds of capital can be built, while potential, as a valuable category, occurs in the phase when we have the possibility to develop the evaluated resource or attractiveness, taking into account the capital stocks. Endogenous development as a process is based on the activation of the characteristic and/or suitable endogenous resources and potential of an area.

\subsection{Human potential - A prerequisite for rural development}

The basis of rural development is represented by people. If a rural area has massive outmigration of young people or an unfavorable age structure, it will be very difficult to initiate 
endogenous economic growth. The human dimension also includes the educational level of the population, their cultural identity and their social structure. Human factors are relevant not only in rural areas: we also have to consider the impact of urban lifestyle changes on rural areas, such as changes in leisure activities or food consumption of the urban majority (Perpar, 2007). The degree of engagement and participation of the local population (together with the local actors) is also an important factor in successful development planning and implementation (Lampič \& Potočnik Slavič, 2007). In the past rural development measures did not sufficiently take into account the human potential. The local population is often not capable of evaluating its own capital or activating numerous sources, which are very often developed through "top-down" help and suitable networking. Social capital is also a very important factor. Partnerships and cooperation between different levels of governance and local actors enhance the possibilities for successful rural areas and enable the exchange of positive experience.

\subsection{Economic potential - Employment possibilities}

If there is no viable economic basis for rural life, there will be no rural life. Other sectors besides agriculture and forestry, such as rural industry or rural services, are gaining in importance. In recent years there have also been economic developments in rural areas that could be summarized under the term "new economy". These include not only facilities and services of the information and communication technology industry, but also biotechnology firms and others. The "new economy" is sometimes combined with traditional production, heritage and tourism. Lack of employment opportunities is a major problem in rural areas in Slovenia. Due to globalization, existing jobs in rural areas are being eliminated and moved to urban areas. At the same time, there are possibilities to reinforce rural economies through diversification of economic activities through entrepreneurship, crafts, supplementary activities on farms and also for non-agricultural activities and services (Perpar, 2007). Support should be directed also to innovation, research and knowledge, and technology transfer.

In the continuation we will focus more on those activities and development potential of rural areas that are most characteristic and most associated with rural development, like agriculture (including organic farming and farm diversification), forestry, rural tourism and renewable energy production. In addition to some general background, we will focus in particular on the situation in Slovenian rural areas.

\subsubsection{Agriculture and rural areas}

Agriculture has played a dominant role in the development of rural areas and in the shaping of rural landscapes and rural settlements, and has had a decisive influence on economic and social life in rural areas. Although agriculture today for many rural areas remains an important economic activity and an important factor for the creation of wealth and employment (both directly and indirectly), its once dominant role in the rural economy is declining (Van Huylenbroeck et al., 2007). But society is formulating new expectations of the role of agriculture, beyond its economic contribution due to food production. In this new context, agriculture is acquiring some other important social, recreational and environmental functions. Agriculture (and the primary sector as a whole) is important also for employment but this varies considerably from one rural area to another, depending on 
the extent to which the primary sector has been modernized and the availability of alternative income options. In most areas in the European Union the primary sector accounts for less than $10 \%$ of total employment. In a third of rural areas its share is less than $5 \%$. However, in some areas its share is still over 25\% (European Commission, 2008). Nowadays we talk about the multifunctionality of agriculture. However, there is no comprehensive definition of this concept. Multifunctionality originates in the supposition that agriculture, apart from the production of food, also has other broader social functions and aspects, such as maintaining production potential, encouraging rural development (maintaining population of rural areas, maintaining the landscape and heritage) and protecting the environment (Majkovič et al., 2005). Generally it is concluded that the multifunctionality of agriculture can be defined as the joint production of commodities and non-commodities by the agricultural sector (Figure 1). Hence multifunctionality refers to the fact that an economic activity may have multiple outputs and may contribute to several societal objectives at once (Majkovič, 2005; Durand \& Van Huylenbroeck, 2003; OECD, 2001). Multifunctionality is therefore argued to be the new unifying paradigm to bring postmodern agriculture in accordance with the new societal demands. It is emphasized that in addition to producing food and fiber, agriculture also produces a wide range of noncommodity goods and services, shapes the environment, affects social and cultural systems and contributes to economic growth. Authors talk about at least four kinds of functions of agriculture. For a more picturesque definition of the individual role of agriculture different colors are used. The "green functions" include landscape management and maintenance of landscape amenities, wildlife management, the creation of wildlife habitat and animal welfare, the maintenance of biodiversity, improvement of nutrient recycling and limitation of carbon sinks. "Blue services" are the other public benefits created by agriculture and comprise water management, improvement of water quality, flood control, water harvesting and creation of energy. "Yellow services" refer to the role of farming for rural cohesion and vitality, ambience and development, making use of cultural and historical heritage, creating



Fig. 1. Agriculture with its multiple function (Majkovič et al., 2005) 
a regional identity and offering hunting, agro-tourism and agro-entertainment. Food security and safety represent the "white functions" of agriculture (Van Huylenbroeck et al., 2007).

The economic and social roles of agriculture contribute significantly to the vitality of rural areas. Today, agriculture is also faced with new challenges arising from globalization of the world economy, population growth, and climate change. These challenges cannot be met without sustainable agricultural and rural development, and clear and effective agricultural and rural development policy.

\subsubsection{Agriculture in Slovenia and its development potentials}

Agriculture in rural areas still presents an important (and in some areas still prevalent) economic activity and a source of employment. The significance of agriculture in the economy of many rural areas is higher than the national average (Perpar, 2007; Perpar \& Kovačič, 2002). Some main characteristics of Slovenian agriculture are the following:

- According to the first provisional data of the 2010 agricultural census, Slovenia has 74,711 agricultural holdings (around 14\% fewer than in 2000) which all together have in use around 476,556 hectares of agricultural land and raise 416,547 livestock units (LU). Compared with the farm structure in most of the European Union, farms in Slovenia are extremely small: on average farms have 6.4 ha of utilized agricultural area (UAA) and keep on average 5.6 livestock units (LU) (SORS, 2011).

- The size structure of farms in Slovenia is not comparable to the size of farms in the European Union. In 2005 23.3\% of farms had less than 2 ha of utilized agricultural area (UAA); $36.1 \%$ have between two and five hectares of UAA, $37.0 \%$ of farms have between 10 and 20 hectares, while only around $4 \%$ farms have more than 20 ha of UAA.

- Fewer than $20 \%$ of farms in Slovenia are full-time (professional) farms, while all the others are too small to ensure the necessary income only from farming, so they must combine additional income sources with additional on-farm activities or with off-farm employment (Udovč et al., 2005).

- The natural conditions for agriculture in Slovenia are not favorable. Almost $85 \%$ of the national territory ( $72.5 \%$ of all utilized agricultural land) belongs to less favorable areas (LFAs), and $60 \%$ of the territory is covered by forests (MAFF, 2008).

- Because the natural and structural conditions in Slovenia to a large extent dictate the orientation of agriculture production, stock farming dominates agricultural production. In plant production field crops dominate, although the production of fruits and grapes represents an important part of the total agricultural production.

- Slovenia is a net importer of agricultural products. The degree of self-sufficiency is higher for animal than for plant products. Permanent surpluses appear only for hops, poultry meat, milk and fresh apples. Supply of beef and meat from sheep and goats is more or less balanced, while a permanent deficit is present for sugar, vegetable oil, vegetables, cereals, fresh fruits (except apples), potatoes, pork, honey and eggs. In wine production the import-export status is changing, Slovenia is a net exporter of quality wine and a net importer of table wine (Perpar \& Udovč, 2010).

- A specific problem faced by Slovenian agriculture is the age structure of farmers on family farms. The share of those younger than 45 years is only $18.8 \%$, a slightly higher share of farmers is seen in the 45 to 55 years age group $(24.3 \%)$, whereas most farmers are more than 55 years old $(56.9 \%)$. 
- Along with unfavorable structure problems of Slovenian agriculture are also considerable fragmentation of the property, low labor intensity of production, low level of professionalization, low level of professional skills among farm holders and workers, and low productivity (0.17 annual work units (AWU) per hectare) (SORS, 2011).

- The share of agriculture in the gross domestic product (GDP) is slightly lower than the European average and comes to just under $2 \%$, while the share of agriculture in total employment is $8.6 \%$ (2008).

Despite the small share of GDP, agriculture's significance in Slovenia is greater than seems at first sight. The multipurpose roles of agriculture in Slovenian rural areas are publicly recognized and financially supported. Despite the unfavorable characteristics and problems mentioned above, agriculture in Slovenia offers much development potential, when all the possible roles that it can play are taken into consideration:

- Due to a low degree of self-sufficiency, the role of agriculture as food producer can be empowered. The importance of local food supply has been recognized as well as a result of an even more unstable food supply on a global level, climate changes with more frequent extreme circumstances and natural catastrophes, globally organized trade chains, decreasing amount of agricultural land due to urbanization, etc. The recognition that locally produced food is of greater quality and healthier, and local production and consumption contribute to the maintenance of the countryside and employment, to protection of the environment, to better soil quality and biodiversity, enhances the importance of locally grown food, giving agriculture new development potential.

- Not only conventional but also organic farming has great potential.

- A great variety of landscapes, local products, natural and cultural heritage offer many possibilities for activities from which agriculture can also benefit (rural tourism, recreation and sport activities, horseback riding, etc.).

- Farms in Slovenia have also been recognized as having potential for the care of elderly people, children or the handicapped (so-called care farms). The idea that farms might be included in the system of social services for people with disabilities is a complete novelty in Slovenia. Vadnal initiated a pilot project of care farming in Slovenia some years ago and put a lot of effort into providing a "space" for such activities in the Agricultural Act, as a precondition for the further development of health/care farming on Slovenian farms. Exploratory research on farmers' readiness to take up health/care farming indicated that there is a particular group of farmers who are willing to start this new activity: holders of smaller farms, aged 45 to 55 years, who used to be part-time farmers but became unemployed due to the reconstruction of the industry. At their age, they can hardly find a new job, and are obliged to make their living on the farm (Vadnal, 2006).

- Part-time farming is an increasingly important feature of rural areas, as agricultural production on family farms is combined with other economic activities. Their potential is to implement some kind of on-farm activities which can be directly connected with agriculture (farm tourism, farm machinery services, food processing, etc.). Because of the small size of Slovenian farms such activities are even more important as an additional source of income and employment of farm family members. Agricultural policy has had special support measures for the diversification of farms for a long time 
already, but greater support and clear legislation are the results of Slovenia's entry into the European Union.

Due to their special importance and potential for rural development, organic farming, supplementary activities on farms, and care farming will be explored in more detail in the continuation. As Darnhofer (2005) noted, farms seeking an alternative may shift their focus from the production of cheap food towards the provision of public goods and services. Involvement in rural development results in new forms of social cohesion as new interrelations are established not only with other farms but also with different segments of the rural and urban population. Farmers try to reduce dependence on external markets and additional income sources with the diversification of their farm activities beyond the production of raw materials. This diversification can take place on-farm and/or within the local economy, within or outside agriculture (Van der Ploeg et al., 2002, as cited in Darnhofer, 2005). Thus rural development activities can be broadened to landscape management, agri-tourism, the production of high quality and region-specific products, direct marketing or new activities such as care activities for the disabled (Figure 2).

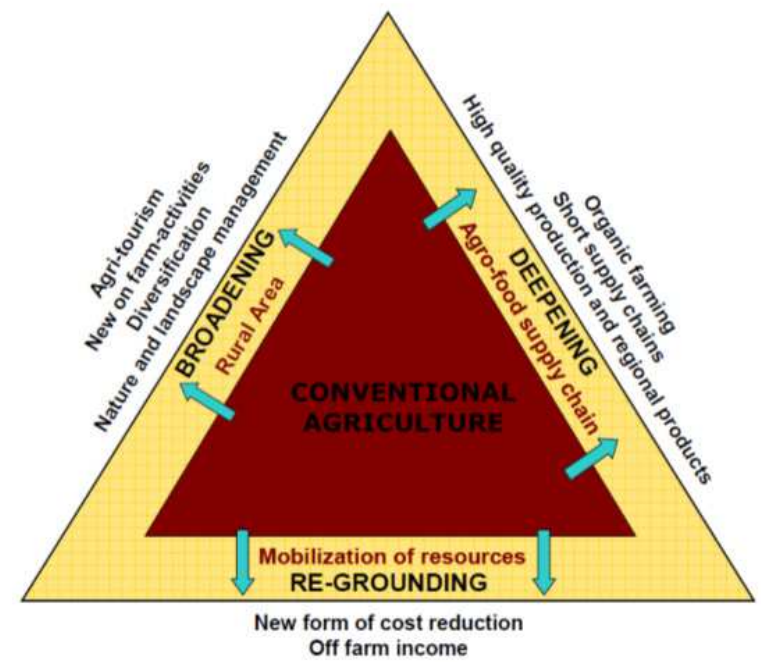

Fig. 2. Multifunctional diversification (Source: Van der Ploeg et al., 2002)

\subsubsection{Organic farming and rural development}

Organic farming is an environmentally friendly agricultural production system and more sustainable than most conventional farming systems. Different authors analyze its positive impact: on the cultural landscape (Tress, 2000, as cited in Darnhofer, 2005), on the creation of employment opportunities in rural areas (Knickel \& Renting, 2002), on increasing farm income (Nieberg \& Offermann, 2002), on better allocation of family labor (Juvančič \& Erjavec, 2005), on possible benefits to the regional economy (Pugliese, 2001). Most studies focused on the on-farm value added, or through on-farm processing or direct marketing. Organic farming is often seen as alternative or short food supply chains (Renting et al., 2003) or as a highly differentiated production that has the capacity to respond to consumer 
concern related to food safety and quality (Zanoli, 2004, as cited in Darnhofer, 2005). As Marsden et al. (1999, as cited in Darnhofer, 2005) note, short food supply chains represent a "defense" strategy against the prevailing trends of globalization and further industrialization of markets, reduction of transport costs and emissions of $\mathrm{CO}_{2}$ (Perpar \& Udovč, 2010), and have an impact on the broader aspect of rural development. Organic farming is thus a way to increase farm income and to restructure farms towards greater diversity and flexibility of farm activities through higher product prices and direct payments and through some requirements (crop rotation, limited external inputs). Conversion to organic farming may thus not only be motivated by economics in the sense of short-term profit maximization, but also by strategies for risk avoidance, regaining control over resources and increasing the quality of life and work on farm and in rural areas in general (Darnhofer, 2005). Organic farming can offer specific synergies that encourage rural development and stimulate more interactions in the rural economy.

\subsubsection{Organic farming in Slovenia}

Organic farming is often seen as a panacea for addressing the environmental, animal welfare and food safety concerns driving Common Agricultural Policy (CAP) adjustment (Darnhofer, 2005). The perceived link between organic farming, on-farm processing and direct marketing, and the potential contribution of short food supply chains to rural development, make it even more attractive to policy makers. Some evidence from studies suggests that organic farming can support a reconfiguration of on-farm activities. This in turn encourages the redirection of resources towards a wider variety of activities, leading to greater involvement in the local economy, in the food sector or outside it. As Darnhofer (2005) notes, these new activities expand income sources and reduce the farm's dependence on commodity prices. A contribution to rural development can be achieved not only through alternative food chains but also through engagement in some supplementary activities on farms.

In the last decade the production of organic food and the consumer demand for organic food have increased significantly in the European Union and in Slovenia. The first Slovenian Organic Farmers Association was founded in 1997, although organic farming in Slovenia began earlier. But this was the first national association of pioneer organic farmers who were producing for the market, and who were therefore interested in the development of a certification system. Standards for organic production/processing were prepared by the Institute for Sustainable Development (ISD) and were available for the first time in 1998 (Slabe, 2000). In 1999 a Slovenian certification body was established and the Ministry of Agriculture, Forestry and Food introduced direct payments for organic farmers, as preconditions for further development of organic farming. Support measures which are available under the agricultural policy resulted in an increased number of organic farms and farms which are converting to organic production. The dynamics of growth are shown in Figure 3. In 2008, organic farming in Slovenia was performed on $2.7 \%$ of farms (2,046 farms) with $4.8 \%$ (29,836 ha) of total agricultural land engaged in such production (SORS, 2011).

We can observe some differences among adopters and non-adopters of organic farming in Slovenia in information adoption and attitudes towards sustainability. The groups of farms use different information sources, and are members in different associations. The level of environmental awareness is higher among adopters, but with respect to many other characteristics the differences are not significant. This indicates that organic farming has a 


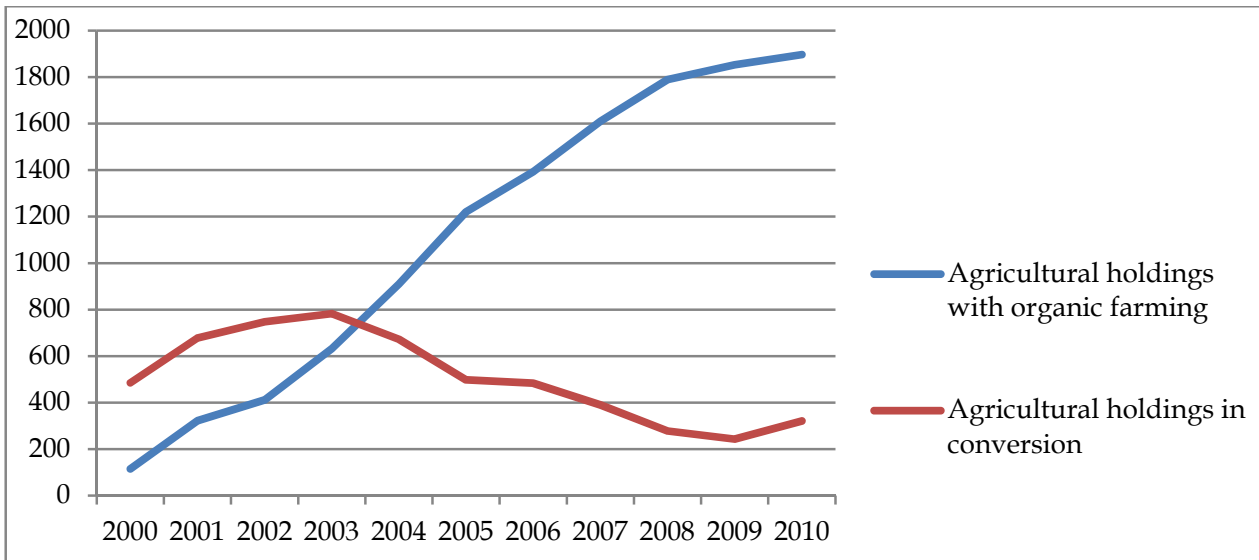

Fig. 3. Agricultural holdings with organic farming and agricultural holdings in conversion, Slovenia 2000 - 2010 (Source: SORS, 2011)

certain development potential in Slovenia, but limited as is the case in other European countries. This is confirmed also by the future plans of non adopters, where a significant proportion of farms are undecided regarding the conversion of their farms to organic agriculture in the next 10 years (Udovč \& Perpar, 2007).

The future success of organic farming in Slovenia depends on the ability to link organic farming and tourism and on the development of organic food processing (Slabe, 2000). Slovenia has a very attractive and well-preserved natural environment. Several conservation areas are now in the process of being established, which may further the development of organic farming in those areas. However, since Slovenian agriculture is unable to compete with cheaper production in other countries due to its natural conditions and the agricultural structure, organic farming may be an important opportunity to produce high-quality food products primarily for the domestic market and for tourist consumption. The demand for organic products in Slovenia is still higher than the domestic supply. With agricultural policy and support measures oriented towards multifunctional agriculture, there is a good chance that the number of organic farms will still grow in the future.

\subsubsection{Supplementary activities on farms}

Due to the fact that in Slovenia there are not many large professional farms and that agriculture in most Slovenian rural areas is not the most important economic activity anymore, diversification on farms has increased over the last decade, mostly as an additional activity on part-time farms which are not big enough to be economically efficient or farms with a surplus of labor. Farms search for additional sources of income mainly through on-farm diversification, mostly farm tourism and/or food processing, but the list of possible supplementary activities ${ }^{1}$ (as we call them in Slovenia) is much broader. Among the activities permitted by the regulation are food processing on the farm, farm tourism, farm

${ }^{1}$ Bryden et al. (1992, as cited in Darnhofer, 2005) refer to such activities as para-agricultural activities. 
mechanization services, provision of renewable energy, educational activities etc. The decision regarding the choice of the type of supplementary activity and the extent of the activity on the farm is based on various factors and their combinations within the farm and also on legislation. The search for additional income sources within rural households is being encouraged by both exogenous and endogenous factors. As exogenous, Potočnik Slavič (2010) noted a lack of employment opportunities in general, unemployment, increased interest in living in a natural environment, increased demand for local agricultural products etc., while endogenous factors are the available resources on the farm (land, people, knowledge and traditions on the farm etc.).

The idea of farm diversification is not new in Slovenia. Some early measures were introduced as early as in the 1970s, with support for the establishment of farm tourism and later also for some other activities. A more noticeable increase in the number of farms implementing some kind of on-farm supplementary activity is evident after agricultural policy reform began in 1999, when diversification on farms was also seen as a "survival strategy" for smaller farms and rural areas in a new European perspective (Slovenia joined the European Union in 2004). From 2004 to the present, the number of registered supplementary activities in Slovenia has been increasing steadily, due also to permanent support measures from the Rural Development Program of Slovenia. 2,215 supplementary activities were registered in 2004 (Klemenčič et al., 2008) and the number increased to 4,716 in 2008 (a 113\% increase). The latest data from the Register of Supplementary Activities (under the supervision of the Ministry of Agriculture, Forestry and Food) shows an increase in the number of registered supplementary activities to $7878^{2}$ (May 2011). This is a further increase of $59 \%$. The possible reasons for the increase are available forms of support and probably also the economic crisis, when many people lost their jobs and hence mobilized their available farm potential.

The introduction of supplementary activities can have both positive and negative effects. As positive Klemenčič et al. (2008) cites additional income for farm family members, improved living standard and social security of farm households, new investments on farms, more interest on the part of the younger generation in staying on the farm etc., while negative effects are more difficult adjustment of different interests within the farm family, disruptions of agricultural production, less free time for family members and more financial risks. When focusing on the reasons why motivated farmers register some kind of on-farm diversification activity, Potočnik Slavič (2010) found that the most important is economic motive, i.e. the need for additional income and better use of available farm assets (economic capital), other important motives are also available agricultural products and family traditions and knowledge (human and social capital).

\subsubsection{Foresty and rural development}

Forestry is increasingly recognized as one of the activities to be considered in rural development; however, there are different opinions about how it can best contribute to it. The reasons for this are the changed meanings of the concept of rural development and

\footnotetext{
${ }^{2}$ The number of farms with registered activities is smaller because each farm can register more than one supplementary activity.
} 
the changing perceptions about the precise role of forestry (Elands \& Wiersum, 2001). In the past, most attention was focused on the primary production function of forests in order to stimulate the economic advancement of rural areas (by providing income, employment and raw materials). Nowadays increasing attention is being given to its role in maintaining and (re)creating ecological and amenity services as a means of contributing towards environmentally attractive living and leisure areas for the rural and urban population. The role of forests can be positive but also negative. As positive we can mention the following:

- At the regional level forests can contribute to the maintenance of an attractive rural landscape, while at the farm level they may contribute towards the development of multi-active farms, in which forest-related production and leisure activities are integrated with agriculture (Elands \& Wiersum, 2001).

- Forests provide some quality products, and maintain biodiversity as well as environmental services (water storage, carbon dioxide reduction, etc.).

- In rural areas with a diversified economic structure the landscape function of forests is important in order to increase the recreational attractiveness of the area. Forests can contribute to the strengthening of the ecological infrastructure in order to increase the natural values of the countryside and add to its recreational attractiveness. New "wilderness" areas can be created and incorporated into rural areas as a means of providing both experience of nature and tranquility for urban people (Mormont, 1987). For remote areas this means that they can best be devoted to large national parks. Ecotourism is often considered as a major economic activity in such areas.

- In areas adjacent to urban agglomerations as well as areas with a diversified economic structure, new forms for the integration of forests with housing estates, business parks and/or recreation facilities are possible.

- Rural forestry development can contribute to the farm and regional economy by optimizing the income-earning capacity. Forestry can contribute to the prevention of economic decline and maintenance of community stability in existing forest areas (Schallau, 1990, as cited in Elands \& Wiersum, 2001). This can be achieved by measures aimed at sustaining forest-dependent communities, e.g. by optimizing labor employment in forest management and forest-related industries, or by optimizing forest production as a complement to farm production (Elands \& Wiersum, 2001).

As a negative aspect of forestry in rural development, Elands and Wiersum (2001) mention that forestry should not become too dominant in any area, because it can endanger the identity of rural areas as areas under the farmer's stewardship and can lead to further marginalization. This can be especially true for remote areas (Selby \& Petäjistö, 1995), where farmers with difficulty accept afforestation. One reason is economic: forests provide fewer employment and income opportunities than agricultural land (especially in the short-term perspective). From the landscape identity perspective, increased forest area means the loss of open agricultural space and loss of attractive landscapes, and at the same time also more damage caused by game.

\subsubsection{Forests and its role for rural development in Slovenia}

Forests cover $60 \%$ of Slovenia's surface area and are one of the most recognizable spatial elements. In terms of forest cover, Slovenia is in third place in Europe, after Sweden and 
Finland. Forests constitute a significant market opportunity and a comparative advantage of Slovenia and its rural areas. Most are in good condition due to sustainable management principles, with good quality timber which is important not only as a raw material for the wood processing industry, but also as an important renewable energy source. Rich forest biodiversity is a result of the diverse natural resources at the intersection of three major climatic systems: the Atlantic, Mediterranean and continental. Predominantly beech, firbeech and beech-oak forests with a relatively high production capacity are involved. $72 \%$ of the forests are privately owned, with the remaining $28 \%$ being owned by the state and municipalities. For the most part Slovenian forests are managed according to the general forest management plans prepared by the Slovenian Public Forest service, which is preparing guidelines for forest management irrespective of ownership based on the concept of sustainable and multi-purpose management. Forest owners as land owners have the right to harvest timber from their forests according to a management plan and sell it on the open market. Two thirds $(67 \%)$ of forest owners own less than 1 ha of forested land, and their combined property covers $9 \%$ of the total forest area. There is a predominance of owners in the category 5 to 15 ha, accounting for $31.1 \%$ of all forest area, followed by owners in the size category of 1 to 5 ha with $27.8 \%$. Just $2 \%$ of Slovenia forest owners own a third $(32.2 \%)$ of all forests in the category over 15 ha size (Medved et al., 2010). Among forest owners there are also members of commons whose property was nationalized in the 1950s and 60s and then returned through the restitution process. Ownership types are not precisely studied by categories which would be comparable over the longer period of time. Among $77 \%$ of private forests we find $30 \%$ of family farms (Medved et al., 2010), common property regime, individual forest owners, who in fact usually co-own their property with their relatives and other institutional owners (e.g. the Church). Such fragmentation makes professional work and optimal wood utilization difficult.

The growing stock and increment of Slovenian forests have been increasing for more than 50 years. According to the Forest Service of Slovenia, growing stock in 2009 amounted to more than 327 million $\mathrm{m}^{3}$, and the annual allowable cut in that year amounted to 3.4 million $\mathrm{m}^{3}$. The annual allowable cut, despite the long tradition of sustainable forest management, is far behind the increment, especially in private forests, so that as forests grow older, the wood quality is worsening. The reasons for the non-utilization of this potential have already been mentioned: fragmentation, poor access for machinery, and long distances to deliver the wood to appropriate places for further transport, which adds significantly to the cost of labor. In recent years, there remain at least 2 million $\mathrm{m}^{3}$ of standing timber, and logging will continue to be increased (intensified forest management); this will have a positive impact on the stability of stands, the quality of the trees and the income from forests. Due to global warming, the habitats of tree species are also changing, and different pests spread much more quickly and cause some damage. Forests are also more exposed to natural disasters (wind, sleet, snow) than in the past, and besides the increased risk of forest tree insects (especially the bark beetle), this is one of the most common reasons for sanitary felling (i.e. of sick and damaged trees). This is about a third of the total harvest and the proportion of nursing required logging. This reduces the planned forest management, and also the ecological stability of forests.

In the structure of forestry production from 2000 to 2009, round wood for industrial use was dominant (including logs for sawmills, veneer wood for pulp and panels and other 
industrial round wood). The value of the share of round wood decreased from $83 \%$ to $66 \%$ from 2000 to 2009, on account of the increased price of firewood. The value of firewood in 2009 amounted to more than $20 \%$ of the total value of production (31 million $€$ ). The share of forestry services also increased (Gale, 2011).

The added value generated by the exploitation of forests in Slovenia is low. The share of value added of forestry in the gross domestic product (GDP) mostly accounted for $0.3 \%$ from 2001 to 2009. In the same period the gross value added per employee in forestry activities increased slightly (Table 3 ). The seasonal nature of employment in forestry must be taken into account, and is measured in annual work units (AWU). One AWU is equivalent to a person who is fully employed in forestry or forestry unit of agricultural activity for one year (1800 hours). In 2009, the gross value added per employee was around $17,000 €$.

\begin{tabular}{|r|r|r|r|r|}
\hline Year & $\begin{array}{c}\text { Production } \\
(\text { mio } €)\end{array}$ & $\begin{array}{c}\text { Gross value added } \\
(\text { mio } €)\end{array}$ & $\begin{array}{c}\text { No. of employees } \\
(\text { AWU) }\end{array}$ & $\begin{array}{c}\text { Gross value added } \\
\text { per employee }(€)\end{array}$ \\
\hline 2001 & 77.7 & 60.1 & 5,033 & 11,936 \\
\hline 2002 & 82.7 & 61.6 & 5,645 & 10,906 \\
\hline 2003 & 93.2 & 68.0 & 5,189 & 13,096 \\
\hline 2004 & 98,1 & 67.5 & 4,653 & 14,511 \\
\hline 2005 & 104.4 & 68.2 & 5,994 & 16,794 \\
\hline 2006 & 150.0 & 98.4 & 5,858 & 18,943 \\
\hline 2007 & 149.1 & 114.4 & 6,037 & 19,520 \\
\hline 2008 & 163.2 & 120.5 & 6,173 & 17,357 \\
\hline 2009 & 152.9 & 105.0 & 6,051 & \\
\hline
\end{tabular}

Source: SORS, 2011, as cited in Gale, 2011.

Table 3. Forestry production, gross value added and employment in Slovenia, 2001-2009

The importance of forests and timber has been increasing in recent times since the processing of wood is not energy extravagant and it is environmentally friendly. For Slovenia, wood as energy is one of the most important renewable energy sources to replace fossil fuels. For energy purposes, in addition to round wood (which is mostly consumed by households) wood waste is also important (these are mainly used in the wood processing industry to meet their own needs for heat and electricity and district heating systems). Total consumption of wood in Slovenia increased slightly in the period 2002-2009: in 2002, more than 2.6 million $\mathrm{m}^{3}$ was used for some energy production and in 2009 just over 3 million $\mathrm{m}^{3}$ of wood.

One recent major area of use of wood is wood construction. Wood is a traditional construction material and an excellent material for buildings of modern architecture, especially in combination with other materials. Wood and wood products are also important for carbon sequestration, which temporarily contributes to a more favorable balance of greenhouse gases. Wood stores carbon dioxide throughout its lifetime. According to the Slovenian Forestry Institute a hectare of forest in Slovenia accumulates in overhead and underground mass about 9 tons of carbon dioxide on average per year (Gale, 2011). Even in the future, forests will play an important role in Slovenia in so-called green energy because the potential of forest biomass is large and not fully utilized. The future of forests, as seen by 
forestry experts and forest holders, lies in their integration within forest proprietors associations, joint wood sales and certification. Forests are not only environmental, but also civilizational and cultural assets of the country, which should be considered in their management and for their integration into rural development through their economic, social and environmental role.

\subsubsection{Rural tourism}

Tourism has become an important activity in the countryside and for the associated rural communities. Lane (1994) defines rural tourism as a complex multi-faced activity which is more than just farm-based tourism. It includes farm tourism but also holidays in nature and eco-tourism, walking, climbing and riding, adventure, sport and health tourism, hunting and angling, educational travel, arts and heritage tourism, etc. Nowadays, a major requirement for rural tourism is to provide peace, quiet and relaxation in rural surroundings. Rural tourism developed intensively in the mid-1990s when it became obvious that the agricultural sector alone was no longer the key to rural development (Verbole, 1999). Tourism has been seen as a possible "savior" for improving the quality of life in rural areas and slowing rural exodus (Garcia Ramon et al., 1995, as cited in Verbole, 1999) by generating additional income for farms and rural communities, creating new jobs, thereby stabilizing the rural economy and providing support for existing business and services and contributing to the creation of new ones.

Rural tourism can have different impacts in and on rural areas. In the general literature three main categories of impact are defined: economic, socio-cultural and environmental (sometimes defined also as physical). Economic impacts are associated with the costs and benefits that result from the development and use of tourist facilities and services, and physical impact with the way tourism contributes to alterations in both the natural and man-made environment, as the two are connected. The socio-cultural impacts are associated with the ways in which tourism contributes to a change in the values system, individual and community behavior, family relationships, collective lifestyles, safety levels, moral conduct, traditional ceremonies and community structure (Mathieson \& Wall, 1982, as cited in Robert \& Hall, 2001).

Positive effects of tourism and recreation in rural areas summarized from different sources (as cited in Robert \& Hall, 2001) are:

- socio-economic: provide a source of new alternative or supplementary income and employment, help to reduce gender and other social power imbalances, encourage collective community activity, provide opportunities for retaining population in areas that might otherwise experience depopulation, enable areas to be repopulated, overall multiplier effects, although in rural areas these tend to be lower;

- cultural: reinvigorate local culture, instill a sense of local pride, self-esteem and identity;

- physical (built and natural): contribute to conservation and protection, assist refurbishment and re-use of abandoned properties;

Negative effects of rural tourism:

- socio-economic: can cause economic leakages, local price inflation, labor in-migration, distort local employment structure, distort local housing market, reinforce perception of 
women's employment as low paid and part-time and an extension of "the domestic role", self-contained complex with tenuous links to the local economy, seasonal patterns of the demand; conflicts in the traditional understanding of land use; a shift in labor away from agriculture towards service industry;

- cultural: manufacture or distort local "culture" for commodification and staged authenticity, destroy endogenous culture; commercialization of rural life;

- physical (built and natural): habitat destruction, littering, emissions and other forms of pollution, congestion, new construction sprawl, perhaps grafted on to existing settlement.

Some of these impacts may have a twofold result, since some may benefit and others not. Of course, not all impacts will necessarily occur in a given local community and/or rural area; their intensity and effect will vary from situation to situation.

The rural tourism development process involves many social actors who continually reshape and transform plans and policy through interaction and negotiation. Local people are not passive recipients of the consequences of rural tourism development policy, but are instead capable of making the most out of a given situation (i.e. initiating a developmental project through the bottom-up approach). It is of vital importance to understand the sociopolitical dynamics of the process taking place within the local communities as rural tourism develops. This is necessary to ensure that the development of rural tourism is sustainable, including allowing for the participation of the local community in development, as well as for participation of all the members in the given community (Verbole, 2000).

Slovenia, as a mostly rural country, has great potential for rural tourism. Different forms of rural tourism have emerged but one of the most important forms is tourism on family farms. Some rural areas of Slovenia, such as Gorenjska and the Upper Savinja Valley, have a long tradition of rural tourism, especially farm tourism. After the Second World War tourism in rural areas stagnated as efforts were redirected to the development of tourist resorts in coastal and mountainous areas. Increase of farm tourism occurred in the late 1970s, fueled in part by the government's growing concern to secure additional income for mountain farmers, related to the small size of the farms, limited production conditions and continuing depopulation trends in some more remote rural areas. Over the last 25 years, various forms of farm tourism have expanded slowly across Slovenia, primarily to provide a secondary source of income for farm family households (Verbole, 1999). These include stationary farm tourism, with farms offering full board, half board or bed and breakfast arrangements, and guests staying either with the farm family or in a guest house; and excursion farm tourism revolving around "open-door farms", where tourists can eat and explore farm life for a few hours, and the recent phenomenon of "camping on the farm". The interest in farm tourism and in other forms of rural tourism increased as the socio-economic situation in Slovenia changed in the late 1980s, owing to the political, economic and social transformations at that time (Verbole, 2000). Privatization, for example, provided the foundations for economic restructuring, including the development of alternative forms of rural tourism, recreational enterprises and attractions and different forms of accommodation. The newly emerging private rural enterprises developed rapidly, providing various activities which include rafting and mountain biking, and they began to compete with family farms for the available resources and income. To be able to follow up the demands and meet the needs of the changing situation in Slovenia's countryside, the Ministry of Agriculture, Forestry and Food 
established a Center for Rural Development and Village Revitalization (CRPOV) in 1991. Subsequently, CRPOV promoted the development of rural areas through specific projects in which rural tourism is often given an important role. Later on, rural tourism was supported through the diversification measures performed in the renewed agricultural and rural development policy of the Ministry of Agriculture, Forestry and Food, while support from the Ministry of Economics was directed to the development of accommodation (mostly in spa resorts in rural areas) and to the general promotion of Slovenian tourism, in which rural areas have great potential due to the diverse natural and cultural heritage (customs, culinary, landscapes, etc). Over the past 10 years the number of tourist farms in Slovenia has doubled and now have a capacity of over 3,000 beds in total. A fine example of humans and nature co-existing in Slovenia are ecological tourist farms. These farms (10 of them right now) offer a healthy living environment and organic food, certified by the official organization.

However, it is argued that rural tourism development should aim at being sustainable and be based on activating local development to realize the endogenous potentials of rural areas in their geographic, cultural and natural diversity. This approach requires coalitions and linkages between different stakeholders such as the state, institutions and local communities and people (Udovč \& Perpar, 2007a).

Protected areas have become one of the most important sources of value and already represent an important part of the tourism infrastructure (information centers, trails, accommodation, etc.) and attraction. 36\% of Slovenia's territory is included in the Natura 2000 network, while protected areas (national park, landscape parks, natural reserves) represent $12 \%$ of the territory. Data show that more than $30 \%$ of foreign tourists come to Slovenia mostly because of unspoiled nature and natural attractions, and also that $30 \%$ of Slovenes spend their free time in nature. In the future, protected areas will be one of the top themes in tourism development. They mean an "above standard offer" with peace, unspoiled nature, and nature-connected activities. Slovenia has great possibilities for sustainable tourism in protected areas because of its diversity; the question is just what kind of tourism and activities are appropriate for protected areas and in what extent (Perpar \& Udovč, 2007). It depends on each protected area's characteristics as well. Recognition of protected areas and their values as well as the appropriate definition of values in these areas can contribute importantly to sustainable rural and regional development. From the standpoint of development, protected areas incorporate environmental, cultural, social and human potential which, according to the protection mode, have certain direct and/or indirect applied value as well as the value of "unused". Protected areas should be understood not only as areas of protection but also as areas of great and in Slovenia not yet recognized and poorly used potential (Lampič \& Mrak, 2008; Zurc \& Udovč, 2009).

\subsubsection{Renewable energy sources}

Energy is one of the main inputs for rural development and economic development. Rural areas have great potential for the production of renewable energy sources: wind power, solar power, hydro-electric power, tidal power, geothermal energy and biomass, which are essential alternatives to fossil fuels. Their use reduces greenhouse gas emissions, diversifies energy supply and reduces dependence on unreliable and volatile fossil fuel markets (in particular oil and gas). The growth of renewable energy sources also stimulates employment 
in Europe, the creation of new technologies and improves the trade balance (European Commission, 2011). Slovenia has great potential for better development of this field, but some problems occur due to some decisions which are sometimes in contradiction with sustainable principles (i.e. competing food and biomass production on the best agricultural land). There is much unused potential from forests, waste etc.

\section{Development potential and rural development policy}

Discussions and concern about the effectiveness of agricultural policy have become increasingly common over the last decade. Special emphasis has been given particularly to agricultural subsidies as the predominant component of public intervention for rural areas, especially in the European Union. Common agreement is that agricultural subsidies bring lots of support into rural areas but they are focused on a small segment of the rural population - farmers and others connected with agricultural production - rather than on rural places or areas. Some findings (OECD, 2006) from the European Union and United States of America suggest that current subsidies-based policies are not effective in addressing some of the most pressing socio-economic challenges facing rural communities, and have uneven impacts across the rural territory. To answer these challenges, policy objectives and instruments have to focus on improving the competitiveness of rural areas using their own capital, thus diversifying economic activities, enhancing business assistance, investing in human and social capital, commercializing and maintaining natural and cultural amenities, finding market niches for local products, providing public services, etc. Thus, rural policy has now gone beyond agricultural policy in many countries, offering new trajectories of development for rural areas (Pezzini, 2001).

In many rural areas employment opportunities in the primary sector are declining, even if farming is still important in shaping rural land use. Some rural areas experiencing outmigration of young people as a result of lack of employment opportunities and inadequate access to educational and leisure activities on the one hand, and in-migration of retirees to some areas on the other, are undergoing aging of the population. Such a demographic structure is often not sufficient to supporting the provision of adequate public services. Rural areas alone often have difficulty providing the necessary critical mass of facilities, producer services and investment to support economic development, so entrepreneurs have difficulty starting up businesses in the area. But some rural areas also show strong economic performance, sometimes even better than some urban areas, so rural areas cannot be treated as synonymous with decline. As Pezzini (2001) noted, macroeconomic policies (ensuring national growth together with stable process and healthy government finances), as well as structural policies (improving the efficiency of markets), will not be sufficient to deal with new and more intense rural problems and challenges. Thus by loosening national ties and enforcing international competition, globalization confronts rural areas both with development opportunities but also with threats not previously encountered. Globalization brings gains to economies in their totality but also poses severe problems of adjustment for many rural areas. Also some traditional territorial polices, concerned with the equitable geographical distribution of resources, are not an appropriate answer to the new conditions engendered by globalization. Pezzini noted that there is a widely held view that a change in emphasis from fiscal policies to endogenous development strategies can add impetus to the restructuring of national economies by reinforcing the capacity for self-generated change. 
Mobilization of local (endogenous) resources and local collective goods to support comparative advantages for local firms, local entrepreneurship and innovation and social cohesion can be better strategies. One of the reasons for change in thinking about rural policy, together with divergent growth patterns, are concerns toward sustainable development. This means a shift in thinking from the idea of development as a process mainly linked with economic growth to the approach based on increases in quality of life and environment. Rural areas are not just quality living places for the rural population but contribute also to the quality of life of society and its public goods such as clean environment, attractive landscapes, natural and cultural heritage, food production capacities, contribution to $\mathrm{CO}_{2}$ reduction, leisure and recreation possibilities, traditional skills and knowledge, people etc. This wide range of resources and amenities (endogenous development potentials) can be a source for future development, either through the direct exploitation of resources or through the creation of conditions for sustainable development of rural areas. Potential economic opportunities, which are a prerequisite for a balanced social and environmental development, range from rural tourism (farm tourism, nature holidays, theme routes, discovery of natural and cultural heritage) to promoting local products (traditional farm products, locally produced materials, crafts, skills, heritage) to attract residents and enterprises to the area. Special attention should be given to improvement of the business environment or to building social and human resource capital. Often endogenous development capacities and entrepreneurship are latent in rural areas (Pezzini, 2001), so some specific measures to encourage them are needed in order to bring out local dynamics of business creation and development. The diversity of rural areas makes it difficult to design a national rural development policy that will take into account local specifics and needs, so active and effective citizen participation in decision making at different levels of government (local, regional, national, international) and cooperation are needed (decentralization of decision making).

Due to the changed situation in rural areas and globally, OECD (2006) suggests three factors that influence rural policy:

1. focus on amenities: the wide range of resources (beyond a narrow focus on agriculture) of rural areas and their use must be taken into account to assure sustainable rural development. The stewardship of the multiple features of rural areas has become a key pillar of place-based policies for rural development.

2. pressures to reform agricultural policy: the question is how to sustain a system of subsidies due to budgetary pressures, international trade agreements; in many cases real farmers are not "happy" with subsidies and want adequate prices for their products instead;

3. decentralization and trends in regional policy: experiences show that just channeling money to rural areas is not enough to solve their problems and help them develop. Policies and programs have to make rural areas more competitive by mobilizing their endogenous development potential. Also regional development policies have to shift from a topdown, subsidy-based strategy to reduce regional disparities to a much broader policy to improve regional competitiveness (focused on infrastructure, the availability of suitable workforce, greater focus on local assets and knowledge, etc.).

OECD (2006) suggested a "new rural paradigm" which is characterized by two principles: a focus on places instead of sectors, and on investment instead of subsidies. The European 
Union in the period 2007-2013 also directed rural policy toward promoting restructuring, modernization and innovation in both agriculture and the wider rural economy (for example measure to support micro-firms in rural areas). Also the LEADER Initiative is one well-known European rural development program, conceived as an integrated and endogenous bottom-up approach to rural development. The program has been widely recognized as a success due its innovative, endogenous potential use character and because of the results obtained in many rural areas despite the relatively limited budget.

Slovenia implemented similar rural development programs to LEADER called CRPOV (Integrated Rural Development and Village Renewal) from 1991 until joining the EU. The program was also based on the local initiative, bottom-up approach, local partnerships and an endogenous approach supported rural people and local communities in diversifying their economies (mostly support for the development of supplementary activities on farms), maintaining rural heritage, village renewal, development of rural tourism, etc. Since joining the European Union, Slovenia has been implementing measures defined in the Rural Development Program for Slovenia 2007-2013 as measures that are enabled in the Common Agricultural Policy (CAP). As a problem from the rural development perspective we can say that these measures do not take into account the situation and specific problems of individual rural areas, which are also very heterogeneous in Slovenia, but they are tailored for general use in EU. Furthermore, regional development policy and rural development policy in Slovenia still have not "met" properly to ensure a synergistic effect.

It is widely argued that rural development policy and practice have to allow diversity in the goals and objectives; it should include economic, social, cultural and environmental dimensions and should allow for democratic processes at all levels. Rural development also does not happen in a vacuum, but is embedded in a given social, economic, political and historical context that has to be taken into account to meet a changing society's needs. One pre-condition for the achievement of a balanced and sustainable development of rural areas is a target-oriented rural development policy, based upon promotion of their endogenous potential and competitive advantages (Juvančič, 2001).

\section{Conclusion}

In the past the countryside was mostly used for its space, natural resources, and workforce needed in the industrial and urban centers. As in many developed countries in Europe and worldwide, development in Slovenia was concentrated mostly in the urban areas. The influence of this process reached the countryside as well, but consideration for the typical characteristics of the rural area and its inhabitants was not sufficient. Consequently, rural areas lagged behind in development, their cultural qualities were disturbed, and development potential was neglected. Hence the demographic situation and the aging structure of the rural population became worse. Simultaneously encountering the environmental and social problems caused mainly by a profit-directed development of modern civilization encouraged the developed societies to discover qualitative possibilities for more acceptable and sustainable development in the countryside and to realize the importance of treating rural areas as a specific subject with its own particularities. Today the development of rural areas receives special attention and most developed states formulate special development policies regarding the needs of the countryside. Research findings show that it is possible to overcome the lagging behind of rural areas through appropriate 
use, empowerment and development of their endogenous development potential. Among the rural areas that have already identified, evaluated and are marketing their potential it is possible to recognize mostly positive economic effects (empowerment of economic capital and higher income), positive demographic trends, better social connectivity and empowerment of social capital, but also stronger and frequent land use conflicts (environmental perspective). The empowerment of endogenous potential improves their development ability, but on the other side the local disparities are even bigger. The positive impact is evident only in local communities that possess the activation capacity of endogenous development potential. According to the theory of complex systems, the contemporary rural system comprises elements of stability and vulnerability. Its development orientations depend on its capability to adjust to wider network factors and sustainable use of its endogenous potential.

\section{References}

Agarwal, S., Rahman, S. \& Errington, A. (2009). Measuring the determinants of relative economic performance of rural areas. Journal of Rural Studies, Vol. 25, No. 3, (July 2009), pp. (309-321), ISSN 0743-0167

Ambrosio-Albalá, M. \& Bastiaensen, J. (2010). The new territorial paradigm of rural development: Theoretical foundations from systems and institutional theories, Institute of policy development and management, Retrieved from http://www.ua.ac.be/objs/00251118.pdf

Barbič, A. (1990). Kmetov vsakdan, Cankarjeva založba, Ljubljana

Darnhofer, I. (2005). Organic Farming and Rural Development: Some Evidence from Austria. Sociologia Ruralis, Vol. 45, No. 4, (October 2005), pp. (308-323), ISSN 00380199

Durand, G. \& Van Huylenbroeck, G. ( 2003). Multifunctionality and Rural Development: a general framework, In: Multifunctional Agriculture. A new paradigm for European Agriculture and Rural Development, Van Huylenbroeck \& Durand, G. (Eds.), pp. (116), Ashgate Publishing Company, ISBN 075463576 7, Wiltshire

ECRD, (1996). Rural Europe - Future Perspectives. The Cork Declaration: "A living Countryside", In: The European Conference on Rural Development, 22. 07. 2011, Available from:

http://www.macaulay.ac.uk/livestocksystems/faunus/corkdec.htm

Elands, B. H. M. \& Wiersum, K. F., (2001). Forestry and rural development: an exploration of socio-political discourses. Forest Policy and Economics, Vol. 3, No. 1-2, (September 2001), pp. (5-16), ISSN 1389-9341

European Commission (2011). Renewable energy targets by 2020, In: European CommissionEnergy, 27. 07. 2011, Available:

http://ec.europa.eu/energy/renewables/targets_en.htm

European Commission. (2008). The EU Rural Development Policy: facing the challenges, 26. 07. 2011, Available from:

http:/ / ec.europa.eu/agriculture/events/cyprus2008/brochure_en.pdf

Fernando, N. A., (2008). Rural Development Outcomes and Drivers, Asian Development Bank, ISBN 978-971-561-629-4, Philippines, Retrieved from:

http://www.adb.org/Documents/Books/Rural-Development-Outcomes-

Drivers/Rural-Development-Outcomes-Drivers.pdf 
Galdeano-Gómez, E., Aznar-Sánchez, J. A. \& Pérez-Mesa, J. (2010). The Complexity of Theories on Rural Development in Europe: An Analysis of the Paradigmatic Case of Amería (South-east Spain). Sociologia Ruralis,Vol. 51, No. 1, (January 2011), pp. (54-78), ISSN 1467-9523

Gale, Š. (2011). Teden slovenskih gozdov 2011, In: Novice Urada za statistiko RS, 23. 05. 2011, Available from: http://www.stat.si/novica_prikazi.aspx?id $=3928$

Halwart, M., Funge-Smith, S. \& Moehl, J.(2003). The role of aquaculture in rural development, In: FAO Inland Water Resources and Aquaculture Service: Review of the state of world aquaculture, 15. 07. 2011, Available:

ftp://ftp.fao.org/docrep/fao/005/y4490e/y4490e04.pdf

Hoggart, H., Buller, H. \& Black, R. (1995). Rural Europe: Identity and Change, Arnold, ISBN 0340596996, London

Juvančič, L. \& Erjavec, E. (2005). Intertemporal analysis of employment decisions on agricultural holdings in Slovenia. Agricultural Economics, Vol. 33, No. 2, (September 2005), pp. (153-161), ISSN 1574-0862

Juvančič, L. (2001). Rural Development Policy in Slovenia: Past Practice and Dilemmas in Adoption of the EU Rural Development Policy Package, In: Policy experiences with rural development in a diversified Europe, 73rd Seminar of the European Association of Agricultural Economists, Ancona, 28-30 June 2001, 29. 03. 2011, Available: http://www.econ.univpm.it/eaae/papers/JUVANCIC.pdf

Klemenčič, M., Lampič, B. \& Potočnik Slavič, I. (2008). Življenjska (ne)moč obrobnih podeželskih območij v Sloveniji, GeograFF 3, Znanstvena založba Filozofske fakultete, ISBN 978961-237-276-7, Ljubljana

Knickel, K. \& Renting, H. (2000). Methodological and conceptual issues in the study of multifunctionality and rural development. Sociologia Ruralis, Vol. 40, No. 4, (October 2000), pp. (512-528), ISSN 0038-0199

Kostov, P. \& Lingard, J. (2001). Integrated rural development-Do we need a new approach? 73rd Seminar of the European Association of Agricultural Economists, Ancona, 20. 07. 2011, Available:

http://www.econ.univpm.it/ricerca/convegni/eaae/papers/KOSTOV.pdf

Lampič, B. \& Mrak, I. (2008). Vrednote, vrednosti in razvojni potenciali območij varovanja. Dela, No. 29, (2008),pp. (145-159), ISSN 0354-0596

Lampič, B. \& Potočnik Slavič, I. (2007). Demographic and human resources as important factors for rural areas development. Bulletin of the Serbian Geographical Society, Vol. 87, No. 2, (2007), pp. (103-114), ISSN 03503593

Lane, B. (1994). What is rural tourism. Journal of sustainable tourism, Vol. 2, No. 1-2, (1994), pp. (7-21), ISSN 0966-9582

Lin, N. (2002). Social Capital: A Theory of Social Structure and Action, Cambridge University Press, ISBN 0-521-47431-0, New York

Lowe, P., Murdoch, J. \& Ward, N., (1995). Networks in rural development: beyond exogenous and endogenous models. In: Beyond modernisation: The Impact of Endogenous Rural Development, Van der Ploeg, J. D., van Dijk, G. (Eds.), pp. (87-105), Van Gorcum, ISBN 902322938X, Assen

Lowe, P., Murdoch, J., Marsden, R. \& Flynn, A. (1993). Regulating the new rural spaces: the uneven development of land. Journal of Rural Studies, Vol. 9, No. 3, (July 1993), pp. (205-222), ISSN 0743-0167 
MAFF (2007). Slovenian Agriculture, Forestry and Food Processing Industry: basic Characteristics and Numbers, Ministry of the Republic of Slovenia of Agriculture, Forestry and Food, ISBN 978-961-6299-86-2, Ljubljana

Majkovič, D., Borec, A., Rozman, Č., Turk, J. \& Pažek, K. (2005). Multifunctional Concept of Agriculture: Just an idea or the real case scenario? Društvena istraživanja, Vol. 14, No. 3, (2005), pp. (579-596), ISSN 1330-0288

Medved, M., Matijašić, D. \& Pisek, R. (2010). Private property conditions of Slovenian forests in 2010 (preliminary results), Proceedings of IUFRO Conference: Small scale forestry in a changing world: opportunities and challenges and the role of extension and technology transfer, Bled, 06-12 June 2010, 25. 07. 2011, Available from:

http://www.gozdis.si/ssfett2010/pdf/P3_4_Medved.pdf

Mormont, M. (1987). Rural nature and urban natures. Sociologia Ruralis, Vol. 27, No. 1, (April 1987), pp. (1-20), ISSN 0038-0199

Nemes, G. (2005). Integrated rural development: The concept and its operation, Institute of Economics, Hungarian Academy of Sciences, Retrieved from: http://www.policy.hu/nemes/publikaciok/muhelytaulmany2005_6.pdf

Nieberg, H. \& Offermann, F. (2002). Does organic farming have a future in Europe? In: EuroChoices, Vol. 1, No. 2, pp. (12-17), (August 2002), 17. 07. 2011, Available: http://onlinelibrary.wiley.com/doi/10.1111/j.1746-692X.2002.tb00082.x/pdf

OECD (2001). Multifunctionality: towards an analytical framework, OECD, Retrieved from: http:/ / www.oecd.org/dataoecd/62/38/40782727.pdf

OECD (2006). The New Rural Paradigm: Policies and Governance, OECD Publishing, ISBN 9264-02390-9, Paris

OECD, (1998). Agricultural Policy Reform and the Rural Economy in OECD Countries, OECD Publishing, ISBN 9264160264, Paris

Perpar, A. (2007). Characteristics of Rural Areas in Slovenia: advantages, weaknesses and possibilities for improvement of present situation from viewpoint of sustainable rural development. Journal of Central European Agriculture, Vol. 8, No. 2, pp. (229236), ISSN 1332-9040

Perpar, A. \& Kovačič, M. (2002). Razvojno stanje, značilnosti in problemi podeželskih območij v Sloveniji. Sodobno kmetijstvo, Vol. 35, No. 2, pp. (52-61), ISSN 0350-1655

Perpar, A. \& Udovč, A. (2007). Rural tourism and protected areas-factors to increase resilience of rural areas. Acta Agriculturae Slovenica, Vol. 89, No. 1, (August 2007), pp. (115-128), ISSN 1581-9175

Perpar, A. \& Udovč, A. (2010). Realni potencial za lokalno oskrbo s hrano v Sloveniji. Dela, No. 34, (2010),pp. (187-199), ISSN 0354-0596

Pezzini, M. (2001). Rural Policy Lessons from OECD Countries. International Regional Science Review, Vol. 24, No. 1, (January 2001), pp. (134-145), ISSN 0160-0176

Potočnik Slavič, I. (2010). Endogeni razvojni potenciali slovenskega podeželja, Znanstvena založba Filozofske fakultete, ISBN 978-961-237-377-1, Ljubljana

Potočnik Slavič, I. (2010). Endogeni razvojni potenciali slovenskega podeželja, GeograFF 7, Znanstvena založba Filozofske fakultete, ISBN 978-961-237-377-1, Ljubljana

Pugliese, P. (2001). Organic Farming and sustainable rural development: A multifaceted and promising convergence. Sociologia Ruralis, Vol. 41, No. 1, (January 2001), pp. (112130), ISSN 0038-0199 
Ray, C. (2006). Neo-endogenous rural development in the EU, In: Handbook of rural studies, Cloke, P. J., Marsden, T. \& Mooney, P. H. (Eds.), pp. (278-290), SAGE Publications, ISBN $076197332 \mathrm{X}$, Wiltshire

Renting, H., Marsden, T. \& Banks, J. (2003). Understanding alternative food networks: exploring the role of short food supply chains in rural development. Environment and Planning - Part A, Vol. 35, No. 3, (March 2003), pp. (393-411), ISSN 0308518X

Robert, L. \& Hall, D. (2001). Rural Tourism and Recreation: Principles to Practice (Reprinted 2003), CABI Publishing, ISBN 085199540 3, Oxon

Selby, J.A. \& Petäjistö, L. (1995). Attitudinal aspect of the resistance to field afforestation in Finland. Sociologia Ruralis, Vol. 35, No. 1, (April 1995), pp. (67-92), ISSN 0038-0199

Shucksmith, M. (2000). Endogenous development, social capital and social inclusion: perspectives from LEADER in the UK. Sociologia Ruralis, Vol. 40, No. 2, (April 2000), pp. (208-218), ISSN 1467-9523

Slabe, A. (2000). Organic farming in Slovenia, 10. 07. 2011, Available from: http://www.organic-europe.net/country_reports/slovenia/default.asp

Slee, B. (1994). Theoretical aspects of the study of endogenous development, In: Born from within: Practice and perspectives of endogenous rural development, Van der Ploeg, J. D., Long, A. (Eds.), pp. (184-194), Van Gorcum, ISBN 902322893 6, Assen

SORS (2011). Pomembnejši podatki Popisa kmetijstva, Slovenija 2010-začasni podatki. In: Novice Urada za statistiko RS, 25. 07. 2011, Available from:

http:/ / www.stat.si/novica_prikazi.aspx?id=3818

Terluin, I. (2001). Rural Regions in the EU: Exploring Differences in Economic Development, Rijksuniversiteit Groningen, Retrieved from: http://dissertations.ub.rug.nl/FILES/faculties/rw/2001/i.j.terluin/thesis.pdf

Udovč, A. \& Perpar, A. (2007). The characteristics of conventional and organic farmers in Podravska region. Acta Agriculturae Slovenica, Vol. 89, No. 1, (August 2007), pp. (8193), ISSN 1581-9175

Udovč, A. \& Perpar, A. (2007a). Role of rural tourism for the development of rural areas. Journal of Central European Agriculture, Volume 8, No. 2, pp. (223-228), ISSN 13329040

Udovč, A., Kovačič, M. \& Kramarič, F. (2006). Socio-ekonomski tipi kmetij po podatkih popisa kmetijskih gospodarstev v letu 2000. Zbornik prispevkov 3. konference DAES: Slovenia v EU-Izzivi za kmetijstvo, živilstvo in podeželje, ISBN 961-91094-2-2, Moravske Toplice, 10-11 November 2005

Vadnal, K. (2006). Farming for health in Slovenia, In: Farming for health, Hassink, J. \& van Majken, D. (Eds.), pp. (249-269), Springer, ISBN 978-1-4020-4540-0, The Netherlands

Van der Ploeg, J. D. \& van Dijk, G. (1995). Beyond modernisation: The Impact of Endogenous Rural Development, Van Gorcum, ISBN 902322938X, Assen

Van der Ploeg, J. D. \& Long, A. (1994). Born from within: Practice and perspectives of endogenous rural development, Van Gorcum, ISBN 902322893 6, Assen

Van der Ploeg, J. D., Long, N. \& Banks, J. (2002). Living countryside. Rural Development Processes in Europe: the State of the Art, ISBN 90-5439-117-0, Doetinchem

Van Huylenbroeck, G., Vandermeulen, V., Mettepenningen, E. \& Verspecht, A. (2007). Multifunctionality of Agriculture: A Review of Definitions, Evidence and Instruments. Living Reviews in Landscape Research, Vol. 1, No. 3, (June 2007), pp. (143), ISSN 1863-7329 
Verbole, A. (1999). Negotiating Rural Tourism Development at the Local Level: A Case Study in Pišece, Slovenia. PhD thesis, Wageningen Agricultural University, ISBN 90-5485-9849 , Wageningen

Verbole, A. (2000). Actors, Discourses and Interfaces of Rural Tourism Development at the Local Community Level in Slovenia: Social and Political Dimensions of the Rural Tourism Development Process. Journal of sustainable tourism, Vol. 8, No. 6, (2000), pp. (479-490), ISSN 0966-9582

Zurc, J. \& Udovč, A. (2009). Local inhabitants' opinion about the Triglav National Park management. Sociologija i prostor, Vol. 47, No. 1, (June 2009), pp. (43-56), ISSN 18465526 


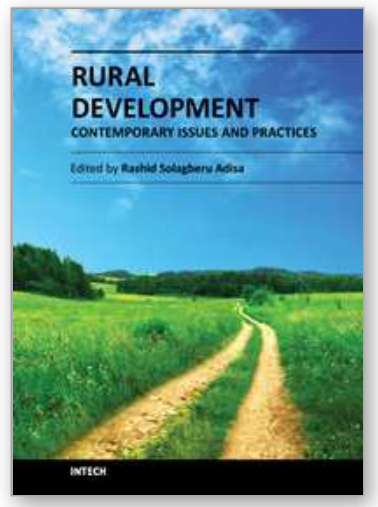

\author{
Rural Development - Contemporary Issues and Practices \\ Edited by Dr. Rashid Solagberu Adisa
}

ISBN 978-953-51-0461-2

Hard cover, 408 pages

Publisher InTech

Published online 20, April, 2012

Published in print edition April, 2012

Development of rural areas has witnessed increasing attention globally, especially over the past three to four decades. The highpoint in the renewed global interest in the development of rural people and their environment was reached with the setting of the Millennium Development Goals (MDGs) in the year 2000. All of the set goals are basically rural development goals. With less than four years to the deadline for the achievement of the MDGs, it is almost certain that the goals are far from being achieved in, especially, most developing countries for whom the MDGs were essentially set. The struggle thus continues for rural development. As long as problems of poverty, disease, illiteracy, unemployment, poor infrastructure, environmental degradation and others persist (or increase) in rural communities, better and more resultoriented solutions to perennial and emerging problems of rural communities would be required. But rural development, in spite of the variations in thresholds of rurality among nations, is not exclusively a Third World or \&lsquo;developing countries\&rsquo; process, owing to its multi-dimensionality. It is a global phenomenon that obviously requires global strategies. This book not only looks at rural development from its multidimensional perspectives, it is also a product of the experiences and expertise of distinguished scholars across the continents. Aiming to provide a comprehensive single volume that addresses salient issues and practices in rural development, the book covers themes ranging from sustainable agriculture, biodiversity conservation, strategic environmental assessment, renewable energy, rural financial resources, assessment of protected areas to statistics for rural development policy. Other subject matters covered by the book include social marginality, land use conflict, gender, cooperatives, animal health, rural marketing, information and communication technology, micro-business, and rural economic crisis. The book is thus an invaluable source of useful information on contemporary issues in rural development for researchers, policy makers, and students of rural development and other related fields.

\title{
How to reference
}

In order to correctly reference this scholarly work, feel free to copy and paste the following:

Anton Perpar and Andrej Udovc (2012). Development Potentials of Rural Areas - The Case of Slovenia, Rural Development - Contemporary Issues and Practices, Dr. Rashid Solagberu Adisa (Ed.), ISBN: 978-953-510461-2, InTech, Available from: http://www.intechopen.com/books/rural-development-contemporary-issuesand-practices/development-potentials-of-rural-areas-the-case-of-slovenia

\section{INTECH}

open science | open minds 


\section{InTech Europe}

University Campus STeP Ri

Slavka Krautzeka 83/A

51000 Rijeka, Croatia

Phone: +385 (51) 770447

Fax: +385 (51) 686166

www.intechopen.com

\section{InTech China}

Unit 405, Office Block, Hotel Equatorial Shanghai

No.65, Yan An Road (West), Shanghai, 200040, China

中国上海市延安西路65号上海国际贵都大饭店办公楼 405 单元

Phone: +86-21-62489820

Fax: $+86-21-62489821$ 
(C) 2012 The Author(s). Licensee IntechOpen. This is an open access article distributed under the terms of the Creative Commons Attribution 3.0 License, which permits unrestricted use, distribution, and reproduction in any medium, provided the original work is properly cited. 